The University of Maine

\title{
DigitalCommons@UMaine
}

Marine Sciences Faculty Scholarship

School of Marine Sciences

$3-1-2002$

\section{Sexually Different Growth Histories of the American Eel in Four Rivers in Maine}

\author{
K. Oliveira \\ James McCleave \\ University of Maine - Main, mccleave@maine.edu
}

Follow this and additional works at: https://digitalcommons.library.umaine.edu/sms_facpub

\section{Repository Citation}

Oliveira, K. and McCleave, James, "Sexually Different Growth Histories of the American Eel in Four Rivers in Maine" (2002). Marine Sciences Faculty Scholarship. 119.

https://digitalcommons.library.umaine.edu/sms_facpub/119 


\title{
Sexually Different Growth Histories of the American Eel in Four Rivers in Maine
}

\author{
Kenneth Oliveira*1 and James D. McCleave \\ School of Marine Sciences, University of Maine, \\ 5741 Libby Hall, Orono, Maine 04469-5741, USA
}

\begin{abstract}
Growth histories of yellow-phase American eels Anguilla rostrata collected in four rivers in Maine, were back-calculated from sagittal otolith increments. Our objectives were to first determine whether sexually dimorphic growth rates exist and then compare the growth histories of American eels from four rivers within a geographic region. For female eels, the maximum growth rate was $31.9 \pm 1.7 \mathrm{~mm} /$ year at age 8 , decreasing to $25.1 \pm 2.9 \mathrm{~mm} /$ year at age 14 . Males attained a maximum of $29.8 \pm 1.6 \mathrm{~mm} /$ year at age 3 , decreasing to a minimum of $17.9 \pm 1.3$ $\mathrm{mm} /$ year at age 11. Females grew faster than males after age 4 and had a slower reduction in growth rate with age. These faster growth rates among females were similar in all four rivers. The observed growth rates are not consistent with current life history hypotheses and may indicate an alternative life history strategy. Because female eels benefit from a larger size (i.e., size refuge, increased fecundity, and greater niche breadth), they would benefit from a higher-risk growth strategy that increases growth rate during their earlier years and reduces the amount of time spent in an unfavorable size-class. The tradeoffs (i.e., mortality, developmental rate, pathogen resistance, and longevity) associated with this faster growth rate may not favor the males' life history requirements. Male eels do not achieve the size of females and therefore are not subject to the advantages associated with being larger. Therefore, they may use a risk-averse strategy that maintains submaximum growth rates to obtain the minimum size necessary to mature and complete the spawning migration while reducing the adverse affects of faster growth rates. We postulate that, in eels, intrinsic growth rates should be considered a life history trait that has evolved to meet the life history requirements of each sex.
\end{abstract}

The American eel Anguilla rostrata is a longlived, commercially exploited species that experiences dramatic changes in habitat and physiology at several times in its life history. The American eel may spend more than 30 years in freshwater (Jessop 1987), where it feeds, grows, undergoes sexual determination and differentiation, metamorphoses to the silver phase, and finally begins the reproductive migration to the Sargasso Sea.

The American eel enters freshwater as a sexually undifferentiated glass eel, beginning the primary feeding and growth phase of its life history. During this so-called yellow eel phase, environmental sex determination is believed to occur in response to local habitat conditions (Colombo and Grandi 1996; Holmgren 1996; Krueger and Oliveira 1999). A relationship between early growth rate and the future sex of an individual has been suggested. In a laboratory experiment, Holmgren and Mosegaard (1996) found that, on average, male European eels Anguilla anguilla gained more

\footnotetext{
* Corresponding author: koliveira@umassd.edu

1 Present address: Department of Biology, University of Massachusetts Dartmouth, 285 Old Westport Road North, Dartmouth, Massachusetts 02747, USA.
}

Received March 22, 2000; accepted August 28, 2001 weight than female eels when within the size ranges that are sexually undifferentiated. A field study examining growth differences before sexual differentiation is required to establish the presence of a natural relationship between early growth and future sex in American eels.

The sexes of eels were hypothesized to develop and mature according to different life history strategies, males using a time-minimizing strategy and females using a size-maximizing strategy (Helfman et al. 1987; Vøllestad 1992; Oliveira 1999). The nature of these strategies suggested that sexually dimorphic growth rates might also have evolved. Male fitness should be enhanced by a growth rate that results in a shorter time to maturation; female eels should have a growth rate that allows a maximum size and fecundity to be attained. However, the presence of sexually dimorphic growth rates in anguillids is questionable. Male European eels may grow faster than females (Eugusa 1979; Holmgren et al. 1997), or female eels may grow faster than males in both the $\mathrm{Eu}-$ ropean eel (Poole and Reynolds 1996) and the American eel (Oliveira 1997, 1999). No study has examined the freshwater growth histories of male and female American eels or the extent to which growth histories may vary among rivers. 
In this study we examined the growth histories of American eels in four Maine rivers with two specific objectives. First was to determine, using back-calculation methods, if and when sexually dimorphic growth rates are present. Back-calculation of fish length-at-age provides an indirect measure of growth, which can be used to compare the growth histories of cohorts, sexes, and populations (Francis 1990). This is especially useful for monitoring long-lived species, which may undergo changes in growth rates due to both intrinsic and extrinsic changes (Lebreton et al. 1999). The second objective was to compare the variability in growth histories of American eels from four rivers within a restricted geographic region where population parameters and life history traits are reportedly similar (Oliveira and McCleave 2000) but growth rate relationships have not been explored.

\section{Methods}

Study area and eel collection.-American eels were collected from four Maine rivers, representing two areas of the state: the Sheepscot $\left(44^{\circ} 00^{\prime} \mathrm{N}\right.$ $69^{\circ} 39^{\prime} \mathrm{W}$ at the river mouth) and the Medomak $\left(44^{\circ} 00^{\prime} \mathrm{N} 69^{\circ} 23^{\prime} \mathrm{W}\right)$ rivers from midcoastal Maine and the Pleasant $\left(44^{\circ} 32^{\prime} \mathrm{N} 67^{\circ} 45^{\prime} \mathrm{W}\right)$ and East Machias $\left(44^{\circ} 42^{\prime} \mathrm{N} 67^{\circ} 23^{\prime} \mathrm{W}\right)$ rivers from eastern Maine (Figure 1). The Sheepscot and Medomak rivers drain 896 and $279 \mathrm{~km}^{2}$ and flow through farmland that has reverted to brush and mixed hardwood forest. The Pleasant and East Machias rivers drain 323 and $794 \mathrm{~km}^{2}$ and flow through peat-land interspersed with blueberry barrens and mixed hardwoods (Ruffing 1991). See Oliveira and McCleave (2000) for more detailed descriptions of the rivers.

Yellow eels were collected in 1996 and 1997 by electrofishing nine sites distributed throughout each river (Oliveira and McCleave 2000). Collected eels were euthanatized in MS-222, measured to the nearest millimeter total length (TL), and decapitated. Bodies were placed in $10 \%$ formalin and heads were frozen for otolith analysis.

Sex was classified as male, female, or undifferentiated by using macroscopic examination of preserved gonads and the microscopic squash method of Guerrero and Shelton (1974). Our examination followed the descriptions of Beullens et al. (1997), with one exception. Gonads that appeared to be stage-4 intersexual gonads (Figure 5 of Beullens et al. 1997) and that apparently lacked oocytes of any stage we classified as males. We believe this method to be conservative and that any errors in identification favored sexually undifferentiated rather than differentiated eels.
Otolith measurements and back-calculation.Sagital otoliths were removed, sectioned in the transverse plane, and prepared for image analysis using methods described in Oliveira (1996). Polished, etched, and stained sections were viewed at 10 or 40 power; larger otoliths required a lower magnification to fit into the field of view. Otolith images were displayed on a computer monitor, and measurements were made using image analysis software. Otolith radius was classified as the distance from the transition mark (Michaud et al. 1988; Lecomte-Finiger 1992; Cieri and McCleave 2001) to the venteral edge of the otolith (Figure 2).

We used the transition mark as a reference point indicating the beginning of freshwater life history, although its formation may not coincide directly with freshwater entry (Cieri and McCleave 2001). A radial measure starting from the transition mark was selected because the mark was a consistently more precise starting point than the primordium, and the transition mark could be seen easily in most otoliths. The radius of each annulus was considered to be the distance from the outer edge of the transition mark to the inner edge of the annulus. This measurement (nearest $0.01 \mathrm{~mm}$ ) was made along the axis of fastest growth and consisted of the sum of several straight-line measurements when the otolith curved (Figure 2). Otolith-ring formation has been shown to be annual in American eels in the northeastern United States (Oliveira 1996). The otolith radii and body lengths were fitted to linear, quadratic, and cubic regression models. Analysis of plots of the residuals showed the data to be heteroscedastic when fit to all models. A natural $\log$ transformation allowed both the quadratic and cubic models to meet the homoscedasticity and normality assumptions of the regression models. The data fit the quadratic and cubic model similarly $\left(r^{2}=0.91\right)$, but the former was the more parsimonious and, therefore, was selected for analysis (Figure 3.). Graphical analysis also showed no heteroscedasity for plots of residuals versus length for either sex or residuals versus mean growth rate.

The body proportional hypothesis (BPH) method described by Francis (1990) was used to back-calculate size at specific annuli. Pierce et al. (1996), using data from two different fish species, concluded that if large sample sizes are used, there are no significant differences in the results of the BPH, scale proportional hypothesis, or Fraser-Lee methods. We used the regression coefficients from the relation of total length to otolith radius to define the parameters of the BPH equation as follows: 


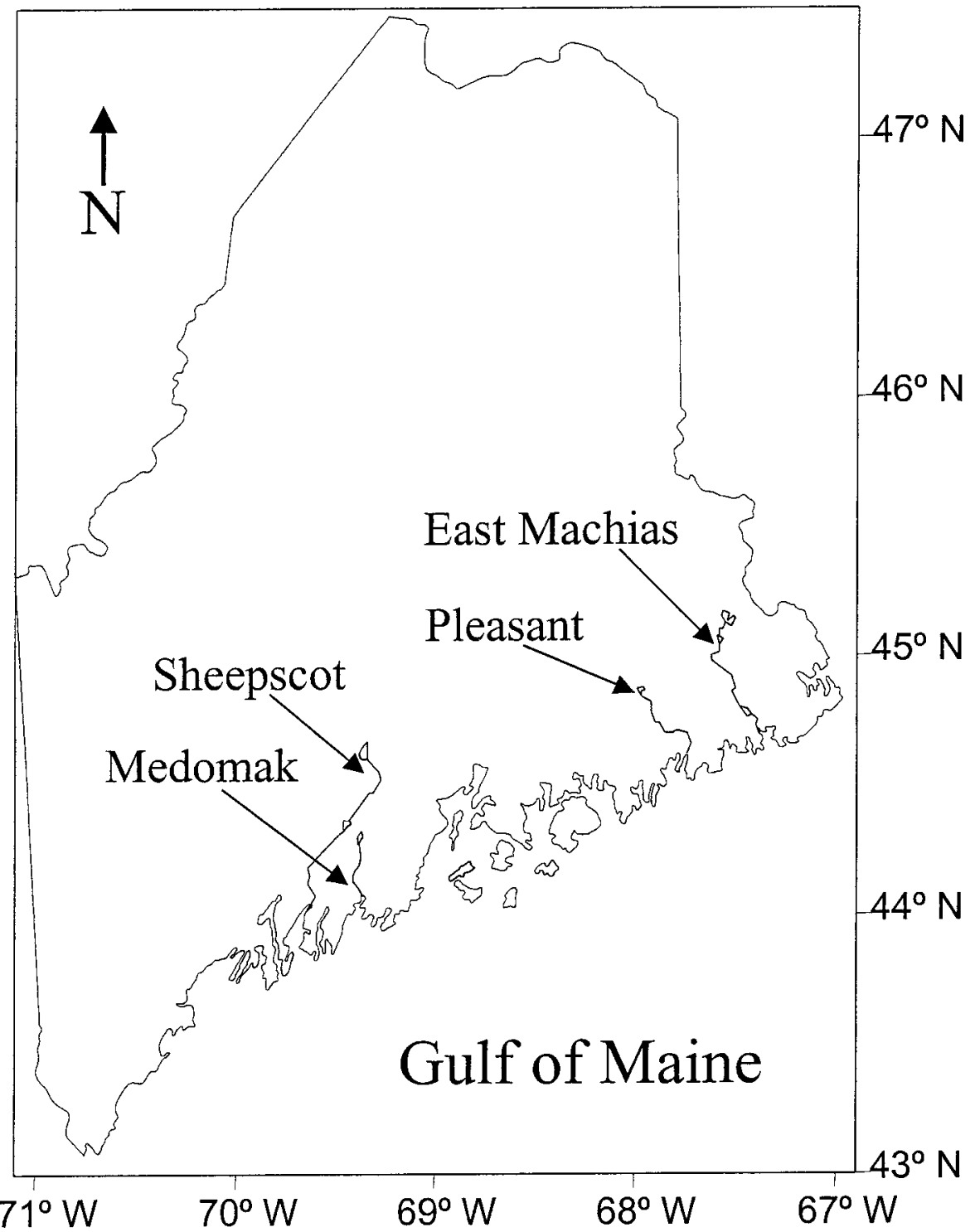

Figure 1.- State of Maine, showing the locations of the Sheepscot, Medomak, Pleasant, and East Machias rivers used in our study of American eel growth.

$$
\begin{aligned}
& \log _{e} \mathrm{TL}_{\text {initial }} \\
&=[ \log _{e} \mathrm{TL}_{\text {capture }}\left(6.1+1.8 \log _{e} \text { radius }_{\text {initial }}\right. \\
&\left.\left.+0.12 \log _{e} \text { radius }_{\text {initial }}^{2}\right)\right] \\
& \div\left(6.1+1.8 \log _{e} \text { radius }_{\text {caputre }}\right. \\
&\left.\quad+0.12 \log _{e} \text { radius }_{\text {capture }}^{2}\right) .
\end{aligned}
$$

Using this back-calculation formula, we obtained length for each year from entrance into freshwater until capture.
Growth comparisons.-Because of the possibility of introducing unknown variation into the analysis, four restrictions were placed on the data. (1) Yellow eel growth rates were calculated beginning with the growth interval between annulus 1 (freshwater year 1) and annulus 2 (freshwater year 2). The interval between the transition mark and the first annulus was not included because of the variability in the timing of the formation of the transition mark. Glass-phase eels may enter freshwater in Maine rivers over several months, thus varying 


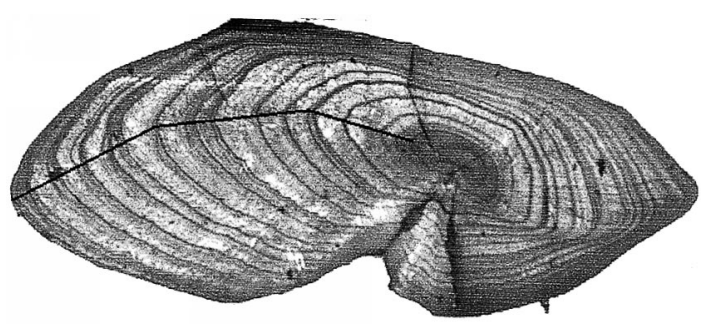

Figure 2.-Photograph of a sagital otolith from an age-13 female yellow-phase American eel, showing the radius as measured in this study. The line indicates the axis of measurement and extends from the edge of the transition zone (central dark area) to the edge of the otolith.

the amount of time available for growth before the formation of the first annulus. (2) Because faster growing yellow eels may metamorphose and leave at an earlier age than slower growing eels, our analyses were restricted to age-2-11 males and age-2-14 females. In these rivers, mean age is 11 years for males and 14 years for females at the silver-phase metamorphosis minus one standard deviation (Oliveira and McCleave 2000). This restriction reduces the chance of slower growing eels being disproportionately represented in the older age-classes. (3) To exclude any unknown sex effects, yellow-phase eels that could not be sexed or had undifferentiated gonads were also omitted. (4) Silver-phase eels were omitted from the growth analysis because the location within the river where their migration began could not be ascertained. These four restrictions allowed growth rates to be obtained from 624 sexually differentiated yellow eels: 150 in the Sheepscot, 97 in the Pleasant, 150 in the Medomak, and 225 in the East Machias rivers.

Data analysis.-Because growth rates were calculated from different age classes from the same individuals, repeated-measures procedures were used to analyze the data. Growth rates resulting from back-calculation were treated equally without regard to the eel's age at time of capture. Each eel provided one growth rate per year of freshwater life after year 1. Repeated-measures procedures in SPSS (1999) do not allow for empty cells, and we desired a sample size of at least 10 eels for each river $\times$ sex cell. This combination restricted statistical analysis to growth rates between ages 2 and 9 for all repeated-measures analyses. The repeated-measures sample sizes were 185 females and 97 males from the four rivers. A mixed-model, repeated-measures analysis of variance (ANOVA) was used to examine growth rates between sexes

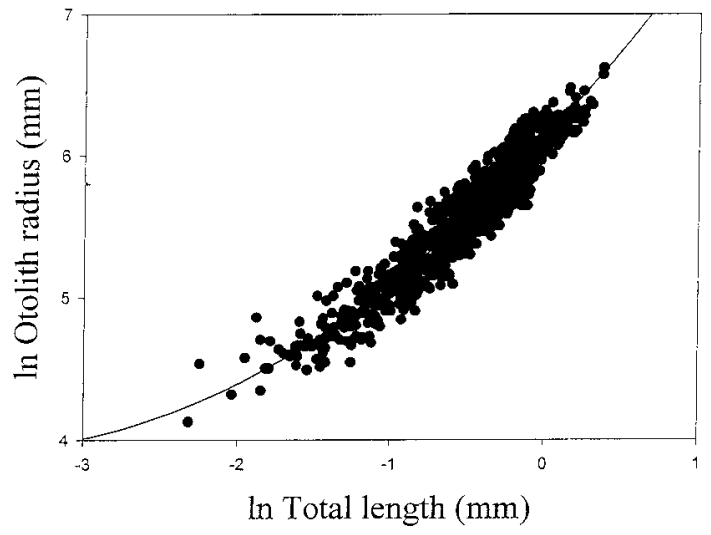

FIGURE 3.- Relationship between total length and otolith radius for yellow phase American eels collected in the Sheepscot, Pleasant, Medomak, and East Machias rivers. $\log _{e}$ total length $=6.1+\left(1.8 \log _{e}\right.$ radius $)+$ $\left(0.12 \log _{e} \text { radius }\right)^{2} ; N=947, R^{2}=0.91$.

and among rivers. Because the variance-covariance of growth was not circular (Mauchly's test of sphericity, $P=0.002$ ), the degrees of freedom for the univariate $F$-tests for interaction components were adjusted using the Huynh-Feldt epsilon value. Mean growth rates are reported for the complete data in the text and in table form for both the complete data and the repeated-measures data.

Pairwise contrasts between rivers were made using an alpha value adjusted with a Bonferroni correction $(P=0.05 / 6=0.008)$. A $t$-test with a modified Bonferroni correction $(P=0.05 / 11=0.005)$ was used to compare pooled growth data between males and females for individual years.

To evaluate the effectiveness of the age restrictions placed on the data, repeated-measures comparisons were made for each sex between the oldest age-group (age 11 for males and age 14 for females) and younger eels ( $\leq 5$ years old) for the first 3 years of growth. The younger eel group contained more age-classes because of the smaller sample sizes of younger eels. All data presented are means $\pm 95 \%$ confidence intervals.

\section{Results}

Overall in the repeated-measures data set mean female growth rate was significantly greater than that of males $(F=18.63$, df $=1, P<0.001)$, although some overlap in growth rates was observed (Figure 4A). The lack of a growth by sex by river interaction $(F=0.91, \mathrm{df}=19.35, P=$ $0.567)$ confirmed that the difference in mean growth rates between sexes was consistent among rivers. 

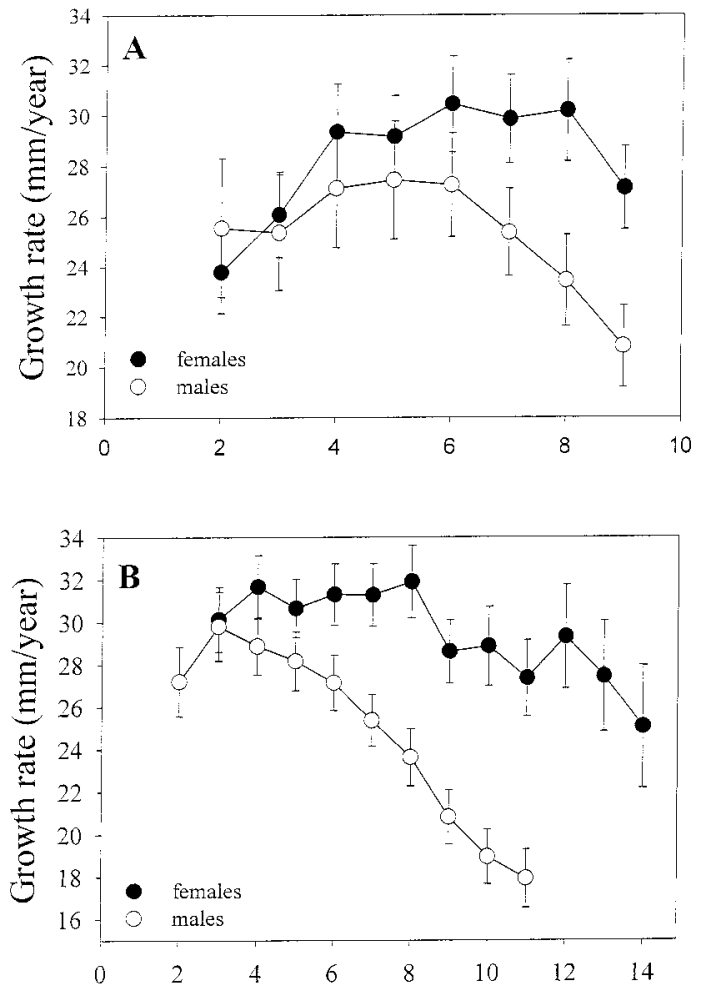

Age (yr)

Figure 4.-Collective mean growth rates $( \pm 95 \%$ confidence intervals) at age for male and female American eels collected in the Sheepscot, Pleasant, Medomak, and East Machias rivers: (A) eels (ages 2-9) that had completely readable growth histories over the 8 -year span required for repeated-measures analysis; (B) all male ( $\leq 11$ years old) and female ( $\leq 14$ years old) eels.

This distinction is clearer when the entire data set is observed (Figure 4B). The year-by-year analysis showed that this distinction became apparent at year 4 and statistically significant at year $6(P$ $<0.001)$. Female eels increased mean growth rate to a maximum of $31.9 \pm 1.7 \mathrm{~mm} /$ year at year 8 , decreasing to $25.1 \pm 2.9 \mathrm{~mm} /$ year at year 14 (Table 1). Males attained a maximum of $29.8 \pm 1.6 \mathrm{~mm} /$ year at year 3 , decreasing to a minimum of 17.9 $\pm 1.3 \mathrm{~mm} /$ year at year 11 . No significant differences between early growth rates of older or younger eels occurred $(F=0.48$, df $=1, P=0.828)$. Indicating that the observed declines were not an artifact caused by the loss of faster-growing individuals from the population.

The statistical analysis of river differences in the repeated-measures data set was performed separately on male and female eels because of the significant differences in growth rates between sexes (Table 1; Figure 4) and the differences in sex ratios among rivers. An overall significant difference was found among rivers for female eels $(F=7.604$, df $=3, P<0.001)$, and pairwise comparisons showed the mean growth rate for female eels in the East Machias River was significantly greater than for Sheepscot River females $(P$ $<0.001$; Figure 5A). Male eel mean growth rate also differed significantly among rivers $(F=5.85$, df $=3, P=0.01$ ), and pairwise comparisons showed that males in East Machias and Medomak rivers had significantly greater mean growth rates than males from the Pleasant or Sheepscot rivers (all four $P<0.001$; Figure 5A). The patterns were similar when the entire data set was considered. The greatest differences occurred during the early years of growth (Figure 5B).

\section{Discussion}

In the absence of a field study validating the changes in otolith size that occur with changes in growth rate, the accuracy of our growth estimates cannot be confirmed. Uncoupling of anguillid otolith growth from somatic growth has been noted in a short-term (8-16 weeks) laboratory study (Holmgren 1996). There also is convincing evidence from other taxa that otolith and somatic growth rates can differ over time (Casselman 1990; Secor and Dean 1992).

However, the residuals in our analysis showed no increase in variability with increases in length or growth rate for either sex. The age restrictions placed on the data may have limited this effect in our study. These results are in agreement with the conclusions of Panfili et al. (1994), who stated that it was uncertain whether uncoupling occurs on a seasonal basis but that a pronounced decrease in otolith growth with increasing fish size confirmed the strong relationship between fish length and otolith size. The high correlation between body size and otolith size and the supporting residual analysis substantiate the differences in growth rates between sexes and the changes in growth rate with age. The essence of our conclusions rely on the relative differences between treatments and not the precise estimation of growth rate.

\section{Differences between Sexes and Rivers}

Females grew significantly faster than males, and growth differences became more pronounced with time. This is consistent with reports for the American eel (Oliveira 1997, 1999) and European 
TABLE 1.-Mean growth rates (mm/year), 95\% confidence intervals $(\mathrm{CI})$, and sample sizes $(N)$ for yellow-phase male and female American eels, ages 2-14 (complete data) versus ages 2-9 (repeated-measures data), from the Sheepscot, Medomak, Pleasant, and East Machias rivers.

\begin{tabular}{|c|c|c|c|c|c|c|c|c|c|c|c|c|c|}
\hline \multirow[b]{2}{*}{ Variable } & \multicolumn{13}{|c|}{ Age (years) } \\
\hline & 2 & 3 & 4 & 5 & 6 & 7 & 8 & 9 & 10 & 11 & 12 & 13 & 14 \\
\hline \multicolumn{14}{|c|}{ All males } \\
\hline Growth rate & 27.2 & 29.8 & 28.9 & 28.2 & 27.1 & 25.4 & 23.6 & 20.8 & 18.9 & 17.9 & & & \\
\hline $95 \%$ CI & 1.6 & 1.6 & 1.3 & 1.4 & 1.3 & 1.2 & 1.35 & 1.3 & 1.3 & 1.3 & & & \\
\hline$N$ & 269 & 269 & 264 & 260 & 252 & 229 & 188 & 152 & 105 & 70 & & & \\
\hline \multicolumn{14}{|c|}{ All females } \\
\hline Growth rate & 27.1 & 30.1 & 31.7 & 31.0 & 31.31 & 31.3 & 31.9 & 28.6 & 28.9 & 27.4 & 29.3 & 27.4 & 25.1 \\
\hline $95 \%$ CI & 1.5 & 1.5 & 1.5 & 1.4 & 1.4 & 1.5 & 1.7 & 1.5 & 1.9 & 1.8 & 2.4 & 2.6 & 2.9 \\
\hline$N$ & 353 & 350 & 344 & 337 & 326 & 311 & 288 & 254 & 216 & 159 & 86 & 86 & 61 \\
\hline \multicolumn{14}{|c|}{ Repeated-measures males } \\
\hline Growth rate & 25.5 & 25.3 & 27.1 & 27.4 & 27.2 & 25.4 & 23.4 & 20.8 & & & & & \\
\hline $95 \%$ CI & 2.7 & 2.3 & 2.3 & 2.3 & 2.0 & 1.7 & 1.8 & 1.6 & & & & & \\
\hline$N$ & 97 & 97 & 97 & 97 & 97 & 97 & 97 & 97 & & & & & \\
\hline \multicolumn{14}{|c|}{ Repeated-measures females } \\
\hline Growth rate & 23.8 & 26.0 & 29.3 & 29.2 & 30.4 & 30.4 & 29.8 & 30.2 & & & & & \\
\hline $95 \% \mathrm{CI}$ & 1.6 & 1.7 & 1.9 & 1.6 & 1.63 & 1.9 & 1.7 & 1.76 & & & & & \\
\hline$N$ & 180 & 180 & 180 & 180 & 180 & 180 & 180 & 180 & & & & & \\
\hline
\end{tabular}

eel (Vøllestad and Jonsson 1986; Panfili et al. 1994; Poole and Reynolds 1996).

Growth rates of the sexes began to diverge at age 4 , the age at which only $5 \%$ of the eels in these rivers were sexually differentiated, but growth rates did not become statistically different until age 6 , when $42 \%$ of the eels were sexually differentiated (Oliveira and McCleave 2000). Because we could not determine the age when an individual eel became sexually differentiated, the potential role of predifferentiation growth rate on the eventual sex of an individual and the role of gonadal development on growth could not be explored further.

Our analysis suggests that the different patterns in the decline of growth rate between the sexes are not attributed to the disproportional loss of faster growing eels that migrate from the population at earlier ages (Lee's phenomena). The differences may be related to different patterns of gonad development. Because male eels metamorphose to the migratory silver phase at smaller sizes and younger ages, they may begin the shift of resources away from somatic growth in favor of gonadal development earlier. This would explain the sharper decline in male growth rate that is evident after age 3. Females metamorphose at greater ages, and therefore they can delay gonadal development. A delayed shift in somatic resources would result in the delayed decline in growth that was observed for females.

Greater female growth compared with male growth was found within all four of the rivers studied, differences in magnitude being the major variation. Previous research on the population parameters of the yellow eels we examined in this study showed no significant differences in sex ratios or in densities (eels $/ \mathrm{m}^{2}$ or $\mathrm{g} / \mathrm{m}^{2}$ ) among rivers or within riverine locations (Oliveira and McCleave 2000). Because environmental factors that affect growth were similar for both sexes, we conclude that under the growth conditions found in these rivers, faster growth is an intrinsic trait of female eels.

Prevailing life history hypotheses for the American eel predicted males to have a faster growth rate than females (Helfman et al. 1987; Oliveira 1999), but we found the opposite. Could faster growth enhance female fitness? Arendt and Wilson (1997) demonstrated that under certain conditions a fish population could evolve a faster intrinsic growth rate. Such a growth strategy enables organisms that are resource limited by competition at smaller sizes to grow faster and spend less time in the less favorable size-class. According to the Arendt and Wilson (1997) model, for a population to evolve a faster growth rate, three criteria must be met. First, there must be competition for resources while in the small size-class. Second, there must be an ontogenetic niche-shift that provides larger individuals greater access to resources. Third, the increase in size also must incur an advantage, such as increased survival due to a reduction in predation. Iwasa (1991) included in- 

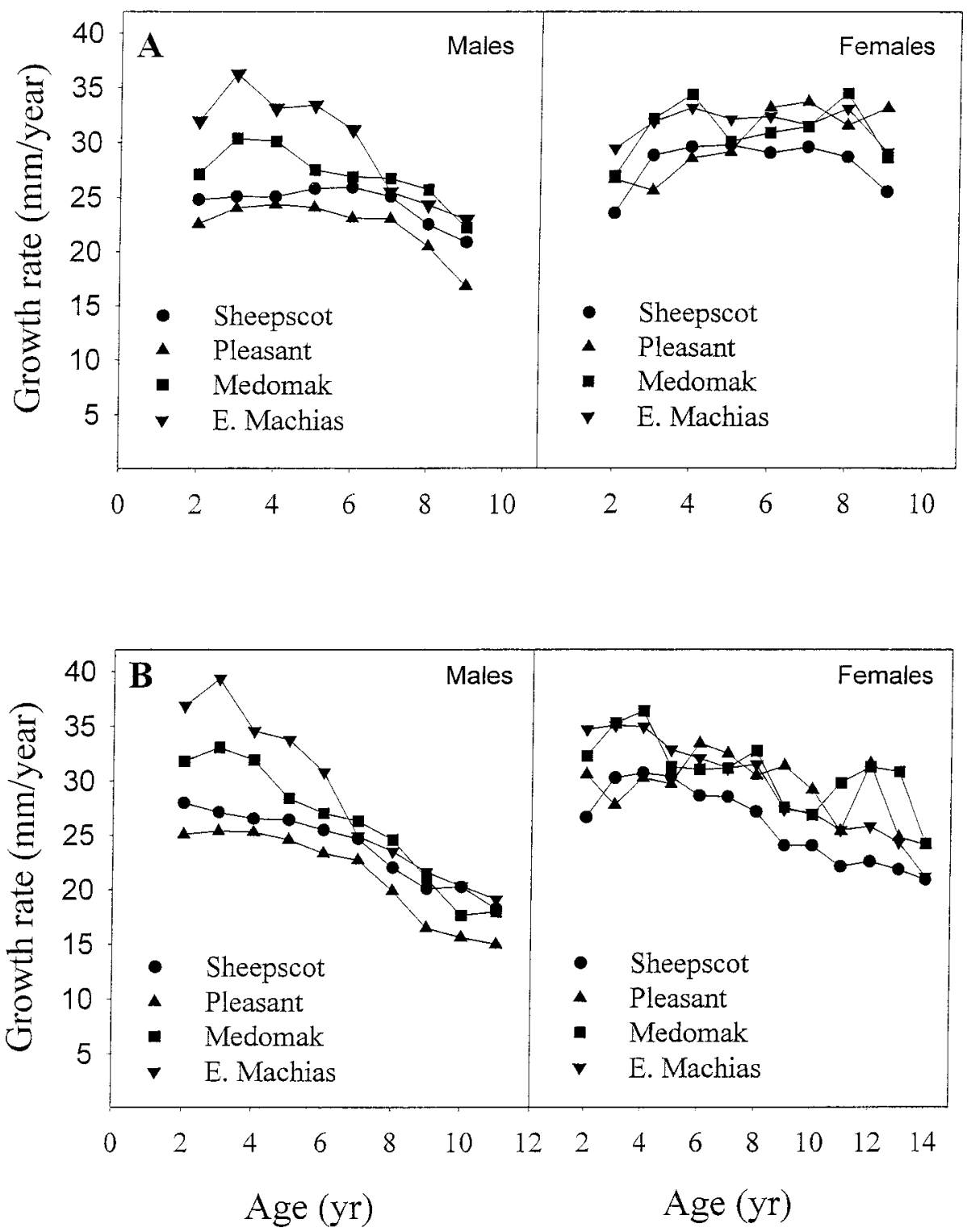

Figure 5.-By-river mean growth rates at age for male and female American eels collected in the Sheepscot, Pleasant, Medomak, and East Machias rivers: (A) eels (ages 2-9) that had completely readable growth histories over the 8-year span required for repeated-measures analysis; and (B) all male ( $\leq 11$ years old) and female ( $\leq 14$ years old) eels. Confidence intervals were omitted to simplify the figure.

creased fecundity with size as an advantage of being larger for plants with this growth strategy. Arendt and Wilson (1997) proposed that maximum growth is not favored in all individuals because of the detrimental effects of the trade-offs associated with faster growth rate (i.e., developmental rate, pathogen resistance, and longevity). The tradeoffs associated with increased foraging (e.g., increased mortality due to predation; Fraser and Gilliam
1987; Werner and Hall 1988; Utne et al. 1997) should also be considered as affecting the evolution of this strategy.

In the case of the eel, this growth strategy would enhance a female's size-maximizing life history strategy by allowing it to achieve a larger size earlier in life. The female eel meets the criteria for this risk-prone strategy. Although all eels are feeding generalists (Helfman et al. 1987), smaller eels 
are more restricted because of the inability to ingest larger food items. Eels do not undergo a dramatic niche shift, but as their size increases, there is an increase in niche breadth characterized by the inclusion of piscivory (Barak and Mason 1992). This shift to piscivory has been shown to occur at about $500 \mathrm{~mm}$ for European eels (Barak and Mason 1992); American eels may become piscivorous as they approach lengths of $400 \mathrm{~mm}$ (Ogden 1970; Lookabaugh and Angermeier 1992). In all studies, eels became picivorous at a size that only female American eels achieve (Krueger and Oliveira 1997; Oliveira and McCleave 2000). Larger size also increases survival (De Leo and Gato 1996) and fecundity (Wenner and Musick 1974; Barbin and McCleave 1997). The delayed development of ovaries (discussed above) would also result in faster growth within the smaller sizeclasses of females.

The slower growth rates of the male eels would be predicted by this growth strategy because males do not meet either of the size-dependent criteria. Males do not achieve sizes that allow for substantial piscivory and therefore an increase in the breadth of their feeding niche. The size range (264-410 mm TL, Oliveira and McCleave 2000) for mature males does not provide as great a size refuge as the female range (from 403 to $1,000 \mathrm{~mm}$ or more TL; Oliveira and McCleave 2000) in these Maine rivers. Because of these size relationships, the tradeoffs that select for faster growth rate in females are not present in males.

Because of the smaller size requirements of males, their fitness may not be enhanced by faster growth rate but, rather, by a reduction in growth related mortality during the yellow phase (feeding and growth phase). Submaximum growth rates will have less effect on the duration of the growth period of males than of females; that is, female fitness is dependent upon size, and they therefore require a larger size at the silver-phase metamorphosis. The lower metamorphic size threshold of males is consistent with the younger ages of males at migration (Helfman et al. 1987; Jessop 1987; Oliveira 1999; Oliveira and McCleave 2000). The hypothesized time-minimizing strategy of male eels (Helfman et al. 1987) might also be described as a risk-averse strategy that maintains submaximum growth rates to enhance survival to the size necessary to achieve the spawning migration.

We propose that the sexes have evolved distinct growth strategies that meet the needs of their respective life history requirements. Female eels may be more risk prone during their earlier years, so they can enter a subsequent niche that allows for the maintenance of a high growth rate later in life. We hypothesize that the presence of specieswide differences in the life history characteristics of the sexes and panmixis should make this growth strategy consistent throughout the species distribution, although our conclusions are based on data collected from a narrow geographic range. We also put forward that, in anguillids, intrinsic growth rates should be considered a life history trait that has evolved to meet the life history requirements of each sex.

\section{Acknowledgments}

Funds were provided by the Eel and Elver management fund of the Maine Department of Marine Resources and Department of Inland Fisheries. We thank Julie Weeder and two anonymous reviewers who provided thoughtful reviews.

\section{References}

Arendt, J. D., and D. S. Wilson. 1997. Optimistic growth: competition and an ontogenetic niche-shift select for rapid growth in pumpkinseed sunfish ( $\mathrm{Le}$ pomis gibbosus). Evolution 51:1946-1954.

Barak, N. A. E., and C. F. Mason. 1992. Population density, growth and diet of eels, Anguilla anguilla L., in two rivers in eastern England. Aquaculture and Fisheries Management 23:59-70.

Barbin, G. P., and J. D. McCleave. 1997. Fecundity of the American eel Anguilla rostrata at $45^{\circ} \mathrm{N}$ in Maine, U.S.A. Journal of Fish Biology 51:840-847.

Beullens, K., E. H. Eding, P. Gilson, F. Ollevier, J. Komen, and C. J. Richter. 1997. Gonadal differentiation, intersexuality and sex ratios of European eel (Anguilla anguilla L.) maintained in captivity. Aquaculture 153:135-150.

Casselman, J. 1990. Growth and relative size of calcified structures of fish. Transactions of the American Fisheries Society 116:161-170.

Cieri, M. D., and J. D. McCleave. 2001. Validation of daily otolith increments in glass-phase American eels Anguilla rostrata (Lesueur) during estuarine residency. Journal of Experimental Marine Biology and Ecology 119:673-688.

Colombo, G., and G. Grandi. 1996. Histological study of the development and sex differentiation of the gonad in the European eel. Journal of Fish Biology 48:493-512.

De Leo, G. A., and M. Gatto. 1996. Trends in vital rates of the European eel: evidence for density dependence. Ecological Applications 6:1281-1294.

Eugusa, S. 1979. Notes on the culture of the European eel (anguilla anguilla L.) in Japanese eel-farming ponds. Rapports et Procès-Verbaux des Réunions Counseil International pour 1" Exploration de la Mer 174:51-58.

Francis, R. I. C. C. 1990. Back-calculation of fish 
length: a critical review. Journal of Fish Biology 36:883-902.

Fraser, D. F., and J. F. Gilliam. 1987. Feeding under predation hazard: response of the guppy and Hart's rivulus from sites with contrasting predation hazard. Behavioral Ecology and Sociobioliogy 21:203-209.

Guerrero, R. D., and W. L. Shelton. 1974. An acetocarmine squash method for sexing juvenile fishes. Progressive Fish-Culturist 36:56.

Helfman, G. S., D. E. Facey, L. S. Hales, and E. L. Bozeman. 1987. Reproductive ecology of the American eel. Pages 42-56 in M. J. Dadswell, R. J. Klauda, C. M. Moffitt, R. L. Saunders, R. A. Rulifson, and J. E. Cooper, editors. Common strategies of anadromous and catadromous fishes. American Fisheries Society, Symposium 1, Bethesda, Maryland

Holmgren, K. 1996. Otolith growth scaling of the eel, Anguilla anguilla (L.), and back-calculation errors revealed from Alizarin labeled otoliths. Nordic Journal of Freshwater Research 72:71-79.

Holmgren, K., and H. Mosegaard. 1996. Implications of individual growth status on the future sex of the European eel. Journal of Fish Biology 49:910-925.

Holmgren, K., H. Wickström, and P. Clevestam. 1997. Sex-related growth of European eel, Anguilla anguilla, with focus on median silver eel. Canadian Journal of Fisheries and Aquatic Sciences 54:27752781.

Iwasa, Y. 1991. Pessimistic plant: optimal growth schedule in stochastic environments. Theoretical Population Biology 40:246-268.

Jessop, B. M. 1987. Migrating American eels in Nova Scotia. Transactions of the American Fisheries Society $116: 161-170$.

Krueger, W. H., and K. Oliveira. 1997. Sex, size and gonad morphology of silver American eels, Anguilla rostrata. Copeia 1997:415-420.

Krueger, W. H., and K. Oliveira. 1999. Evidence for environmental sex determination in the American eel, Anguilla rostrata. Environmental Biology of Fishes 55:381-389.

Lebreton, G. T. O., F. W. Beamish, and R. G. Wallace. 1999. Lake sturgeon (Acipencer fluvescens) growth chronologies. Canadian Journal of Fisheries and Aquatic Sciences 56:1752-1756.

Lecomte-Finiger, R. 1992. Growth history and age at recruitment of European glass eels (Anguilla anguilla) as revealed by otolith microstructure. Marine Biology 114:205-210.

Lookabaugh, P. S., and P. L. Angermeier. 1992. Diet patterns of American eel, Anguilla rostrata, in the James River drainage, Virginia. Journal of Freshwater Ecology 7:425-434.

Michaud, M., J. D. Dutil, and J. J. Dodson. 1988. Determination of the age of young American eels, $A n$ guilla rostrata, in fresh water, based on otolith surface area and microstructure. Journal of Fish Biology 32:179-189.

Ogden, J. C. 1970. Relative abundance, food habits, and age of the American eel, Anguilla rostrata (Le-
Sueur), in certain New Jersey streams. Transactions of the American Fisheries Society 99:54-59.

Oliveira, K. 1996. Field validation of annular growth rings in the American eel, Anguilla rostrata, using tetracycline-marked otoliths. U.S. National Marine Fisheries Service Fishery Bulletin 94:186-189.

Oliveira, K. 1997. Movements and growth rates of yellow-phase American eels in the Annaquatucket River, Rhode Island. Transactions of the American Fisheries Society 126:638-646.

Oliveira, K. 1999. Life history characteristics and strategies of the American eel, Anguilla rostrata. Canadian Journal of Fisheries and Aquatic Sciences 56:795-802.

Oliveira, K., and J. D. McCleave. 2000. Variation in population and life history traits of the American eel, Anguilla rostrata, in four rivers in Maine, U.S.A. Environmental Biology of Fishes 59:141151.

Panfili, J., M. C. Ximenes, and A. J. Crivelli. 1994. Sources of variation in growth of the European eel (Anguilla anguilla) estimated from otoliths. Canadian Journal of Fisheries and Aquatic Sciences 51: 506-515.

Pierce, C. L., J. B. Rasmussen, and W. C. Leggett. 1996. Back-calculation of fish length from scales: empirical comparison of proportional methods. Transactions of the American Fisheries Society 125:889898.

Poole, W. R., and J. D. Reynolds. 1996. Growth rate and age at migration of Anguilla anguilla. Journal of Fish Biology 48:633-642.

Ruffing, J. 1991. Estuary profile series: Maine coastal program. Maine State Planning Office, Augusta.

Secor, D. H., and M. D. Dean. 1992. Comparison of otolith-based back-calculation methods to determine individual growth histories of larval stripped bass, Morone saxatilis. Canadian Journal of Fisheries and Aquatic Sciences 49:1439-1454.

SPSS. 1999. SPSS base 10.0 user's guide. SPSS, Chicago.

Utne, A. C. W., E. Braennaes, and C. Magnhagen. 1997. Individual responses to predation risk and food density in perch (Perca fluviatilis L.). Canadian Journal of Zoology 75:2027-2035.

Vøllestad, L. A. 1992. Geographic variation in age and length at metamorphosis of maturing European eel: environmental effects and phenotypic plasticity. Journal of Animal Ecology. 61:41-48.

Vøllestad, L. A., and B. Jonsson. 1986. Life-history characteristics of the European eel Anguilla anguilla in the Imsa River, Norway. Transactions of the American Fisheries Society 115:864-871.

Wenner, C., and J. A. Musick. 1974. Fecundity and gonad observations of the American eel, Anguilla rostrata, migrating from the Chesapeake Bay, Virginia. Journal of the Fisheries Research Board of Canada 31:1387-1391.

Werner, E. E., and D. J. Hall. 1988. Ontogenetic habitat shifts in bluegill: the foraging rate-predation risk trade-off. Ecology 69:1352-1366. 